Weel, C. van, Schellevis, F.G. Comorbidity and guidelines: conflicting interests. Lancet: 2006, 367(9510), 550-551

\begin{tabular}{|l|l|}
\hline $\begin{array}{l}\text { Postprint } \\
\text { Version }\end{array}$ & 1.0 \\
\hline Journal website & $\underline{\text { http://linkinghub.elsevier.com/retrieve/pii/S0140-6736(06)68198-1 }}$ \\
\hline Pubmed link & $\underline{\text { http://www.ncbi.nlm.nih.gov/pubmed/16488782 }}$ \\
\hline DOI & $10.1016 /$ S0140-6736(06)68198-1 \\
\hline
\end{tabular}

This is a NIVEL certified Post Print, more info at http://www.nivel.eu

\title{
Comorbidity and guidelines: conflicting interests
}

\author{
CHRIS VAN WEEL, FRANÇOIS G SCHELLEVIS
}

Department of General Practice, Radboud University Medical Centre, Nijmegen 6500 HB, Netherlands (CvW); and Netherlands Institute for Health Services Research, Utrecht, Netherlands (FGS)

The fourth epidemiological transition is characterised by an unprecedented increase in chronic degenerative disorders. ${ }^{1}$ Thus chronic disease is a particularly important area in which to ensure high-quality care. Clinical practice guidelines are increasingly being used for performance indicators. Stephen Campbell and colleagues recently showed substantial improvement in the quality of clinical care in UK general practice when judged on this basis. ${ }^{2}$ Reassuring as this result is, this method ignores the reality that $25-50 \%$ of people with a chronic disease have comorbidity or multimorbidity (table). ${ }^{3-7}$

Comorbidity is a regular feature of general practice. However, evidence-based diagnostic and treatment strategies generally overlook comorbidity. ${ }^{8}$ Despite the support that diseasespecific guidelines give, these guidelines are likely to introduce more problems than they solve when used in patients with comorbidity. Treatment or even diagnosis of a disease ${ }^{9}$ might interact negatively with the treatment or natural course of a co-existing disease. For example, in chronic obstructive pulmonary disease, state-of-the-art treatment might include oral corticosteroids, but if the patient also has diabetes mellitus, oral corticosteroids might not be in the patient's best interests. Promotion of physical activity - which would be beneficial for chronic obstructive pulmonary disease-might not be possible if there is severe osteoarthritis of the hip. Conversely, hip replacement, indicated by the severity of the osteoarthritis, will be contraindicated if a patient's pulmonary capacity precludes major anaesthesia. These examples show why performance indicators based on single-disease guidelines cannot accurately reflect the quality of care with multiple chronic diseases. Dealing with comorbidity needs a patient-centred rather than a disease-oriented approach. Addressing individual needs while integrating various disease perspectives is at the root of general practice and determines its effectiveness. ${ }^{10}$

Often implicit in the approach to comorbidity is the assumption that the co-existing diseases are pathophysiologically related to the index disease or represent a disease-specific complication. To some extent this is the case: because chronic obstructive pulmonary disease is caused by smoking, the patient may also have bronchial cancer, ischaemic heart disease, heart failure, or pulmonary hypertension. In these cases it is possible that a disease-specific management plan could address all diseases involved. But this only accounts for part of the comorbidity. Using our findings ${ }^{5}$ we divided comorbidity into four categories: causal, diseases with a common pathophysiology; complicating, disease-specific complicating morbidity; concurrent, co-existing chronic morbidity without any known causal relation to the index disease; and intercurrent, referring to interacting acute illness, usually limited in time. ${ }^{11}$

This categorisation has implications for patients' care. When the comorbidity is causally related to or is a complication of the index disease, disease-specific guidelines can be used to 
Weel, C. van, Schellevis, F.G. Comorbidity and guidelines: conflicting interests. Lancet: 2006, 367(9510), 550-551

direct management. However, these guidelines must include information on the full spectrum of health risks associated with the index condition. Such guidelines would enhance proactive management of illness, but their development will require patients with a mix of comorbid conditions to be included in randomised trials. ${ }^{12}$

The problems with disease-specific guidelines come to the fore when there is concurrent morbidity, particularly in ageing-related diseases when comorbidity is linked to frailty. ${ }^{13}$ The interacting effects of diseases and their management require more complex and individualised care than simply the sum of separate guideline components. And it is only to a limited extent possible to account for this in the framework of guidelines, where statements on management are by definition directed at subgroups. Instead of advocating the development of new guidelines taking all possible combinations of diseases into account, we would emphasise a holistic patient-centred approach, ensuring continuity of care and integrating the patients' biopsychosocial domains. There is an urgent need-particularly in primary care - to test the impact of guidelines. Given the problems of randomisation, blinding, and other methodology, we also welcome studies that combine therapeutic approaches ${ }^{14}$ or report the natural course of patients with comorbid illness.

\section{[TABLE 1]}

We declare that we have no conflict of interest.

1Olshansky SJ, Ault AB. The fourth stage of the age of delayed degenerative diseases. Milbank Q 1986; 64: 355-91.

2 Campbell SM, Roland MO, Middleton E, Reeves D. Improvements in quality of clinical care in English general practice 1998-2003; longitudinal observational study. BMJ 2005; 331: 1121-25.

3 Feinstein AR. The pre-therapeutic classification of co-morbidity in chronic disease. J Chron Dis 1970; 23: 455-68.

4 van den Akker M, Buntinx F, Metsemakers JF, Roos S, Knottnerus JA. Multimorbidity in general practice: prevalence, incidence, and determinants of co-occuring chronic and recurrent diseases. J Clin Epidemiol 1998; 51: 367-75.

5 Schellevis FG, van der Velden J, van der Lisdonk E, van Eijk JThM, van Weel C. Comorbidity of chronic diseases in general practice. J Clin Epidemiol 1993; 46: 469-73.

6 Westert GP, Jabaaij L, Schellevis FG, eds. Morbidity, performance and quality in primary care: Dutch general practice on stage. Oxford: Radcliffe Publishing, (in press).

7 van Weel, C. Chronic diseases in general practice: the longitudinal dimension. Eur J Gen Pract 1996; 2: 17-21.

8 Boyd CM, Darer J, Boult C, Fried LP, Boult L, Wu AW. Clinical practice guidelines and quality of care for older patients with multiple comorbid diseases. JAMA 2005; 294: 71624.

9 Nuyen J, Volkers AC, Verhaak PFM, Schellevis FG, Groenewegen PP, van den Bos GAM. Accuracy of diagnosing depression in primary care. Psychol Med 2005; 35: 1185-95.

10 Starfield B, Lemke KW, Bernhardt T, Foldes SS, Forrest CB, Weiner JP. Comorbidity: implications for the importance of primary care in 'case' management. Ann Fam Med 2003; 1: 8-14.

11 Schellevis FG, van de Lisdonk EH, van der Velden J, Hoogbergen SHJL, van Eijk JTM, van Weel $\mathrm{C}$. Consultation rates and incidence rates of intercurrent morbidity among patients with chronic disease in general practice. Br J Gen Pract 1994; 44: 259-62.

12 Gurwitz JH, Col NF, Avorn J. The exclusion of the elderly and women from clinical trials in acute myocardial infarction. JAMA 1992; 268: 1417-22.

13 Fried LP, Ferrucci L, Darer J, Williamson JD, Anderson G. Untangling the concepts of disability, frailty, and comorbidity: implications for improved targeting and care. J Gerontol A Biol Sci Med Sci 2004; 59: M255-63. 
Weel, C. van, Schellevis, F.G. Comorbidity and guidelines: conflicting interests. Lancet: 2006, 367(9510), 550-551

14 van Os TW, van den Brink RH, Tiemens BG, Jenner JA, van de Meer Kr, Ormel J.

Communicative skills of general practitioners augment the effectiveness of guideline-based depression treatment. J Affect Disord 2005; 84: 43-51.

\section{TABLES}

\begin{tabular}{|c|c|c|c|}
\hline \multirow{2}{*}{$\begin{array}{l}\text { Number of chronic } \\
\text { dieseses* }\end{array}$} & \multirow{2}{*}{$\begin{array}{l}\text { Self-reported } \\
\text { Dutchsurvey } \uparrow\end{array}$} & \multicolumn{2}{|c|}{ General practice) } \\
\hline & & $>65$ years & $>75$ \\
\hline 0 & 43 & 34 & 31 \\
\hline 1 & 26 & 27 & 29 \\
\hline 2 & 14 & 22 & 25 \\
\hline$\geq 3$ & 17 & & 15 \\
\hline \multicolumn{4}{|c|}{$\begin{array}{l}\text { "From list of } 19 \text { for Dutch survey, and of } 10 \text { for general practice studf. } \uparrow A \mid \text { ages, } \\
n=12699 \text {, } n=12000 \text {. }\end{array}$} \\
\hline \multicolumn{4}{|c|}{$\begin{array}{l}\text { Table: Percentage of patlents with chronic diseases in Netherlands } \\
\text { from Dutch population-based health-Interview survey' and general } \\
\text { practice-based continuous morbidity registration' }\end{array}$} \\
\hline
\end{tabular}

